\title{
Addressing the Cosmological Significance of a Pot: A Search for Cosmological Structure in the Craig Mound
}

Shawn Lambert

Mississippi State University

Follow this and additional works at: https://scholarworks.sfasu.edu/ita

Part of the American Material Culture Commons, Archaeological Anthropology Commons, Environmental Studies Commons, Other American Studies Commons, Other Arts and Humanities Commons, Other History of Art, Architecture, and Archaeology Commons, and the United States History Commons

Tell us how this article helped you.

This Article is brought to you for free and open access by the Center for Regional Heritage Research at SFA ScholarWorks. It has been accepted for inclusion in Index of Texas Archaeology: Open Access Gray Literature from the Lone Star State by an authorized editor of SFA ScholarWorks. For more information, please contact cdsscholarworks@sfasu.edu. 


\section{Addressing the Cosmological Significance of a Pot: A Search for Cosmological Structure in the Craig Mound}

\section{Creative Commons License}

\section{(c) (1) \&}

This work is licensed under a Creative Commons Attribution-NonCommercial 4.0 International License 


\title{
Addressing the Cosmological Significance of a Pot: A Search for Cosmological Structure in the Craig Mound
}

\author{
Shawn Lambert \\ University of Oklahoma
}

Ceramic vessels and cosmological structure at first may seem quite unrelated. Many argue the basic and perhaps only function of a pot was a simple human-made container which held foodstuff for cooking and serving purposes. Pre-Contact communities also used ceramics to display complex iconography, some of which may represent important cosmological meanings in time and space. For this paper, I examine the temporal and spatial placement of pottery in 98 Craig Mound burials at the Spiro site in search for cosmological patterns in the imagery of the vessels. Only burials unassociated with the Great Mortuary and the Spirit Lodge were considered, because they have been seriously understudied. Spatial and temporal patterns that emerged from this study suggest burials outside of the Great Mortuary and the Spirit Lodge were also placed in specific areas of the Craig Mound to represent a cosmogram or a ritual display that expressed an important cosmological narrative.

\section{Introduction}

Ceramic vessels and cosmological structure at first may seem quite unrelated. Many have argued that the basic and perhaps only function of a pot is simply a humanmade container for cooking and serving purposes. In this view, decorative elements and motifs adorned on pots are not seen as culturally meaningful. Rather, they have been interpreted as more mundane objects. Any related decorations become the by-products of that function, and as a result, we lose a significant amount of research value (Pauketat and Emerson 1991). This paper emphasizes that non-representative decorative patterns on Caddo pottery at the Spiro site may have functioned as objects by which individuals connected to other cosmological realms. Overall, this research suggests that Craig Mound participants used decorated pottery to highlight and express Above and Below World narratives.

Accordingly, I examine the symbolism and placement of pottery in the Craig Mound burials, which are located at the Spiro site in eastern Oklahoma. Only burials that are not in context with the Great Mortuary or the Spirit Lodge are considered here, because they have been severely understudied. The results of this study show that burials outside of the Great Mortuary and the Spirit Lodge seem to be deposited in specific areas of the Craig Mound perhaps to represent a cosmogram, a religious display that helped to convey an important cosmological narrative.
A complete understanding of pre-Columbian cosmological meaning is beyond the scope of this paper and most likely beyond our archaeological grasp. However, the combination of iconographic elements that denote each cosmological world, in addition to their discrete placement within the Craig Mound, may highlight a religious configuration that Craig Mound participants followed to access specific powers and ritual knowledge from each cosmological world. Separating out each cosmological world through time and space may have also been necessary for religious practitioners to create a powerful tableau that produced an important narrative that expressed a broader Southeast Native American belief system. Also, this analysis has revealed that during the initial stages of Craig Mound construction, Craig Mound participants incorporated highly decorative pottery in burials that were not associated with the Great Mortuary or the Spirit Lodge that may have expressed an important cosmological structure. By the beginning of the fifteenth century, however, when the Great Mortuary and the Spirit Lodge were constructed, it appears that utilizing decorated pottery fell out of favor to other material types to express other ritual narratives (Brown 2012). This significant material alteration may be associated with the increased social interactions between Caddo communities and other major mound centers, such as Cahokia in the American Bottom and Moundville in the Black Warrior Valley (Steponaitis et al. 2015). 
First, I discuss the Spiro site in eastern Oklahoma. Then, I consider the pros and cons in using ethnographic analogies to interpret iconography. Next, I discuss and ethnographically examine the ways in which Native American groups constructed their cosmological worlds. Then, I discuss research regarding Southeastern Ceremonial Complex (SECC) imagery and materials and how ceramics play an important role in iconographic studies. Lastly, I examine and discuss a very intriguing ceramic vessel found in the Craig Mound that depicts complex motifs, compositions, and themes that sheds light on Caddo cosmology as well as showcases the importance of incorporating other Craig Mound ceramics into broader iconographic research efforts.

\section{The Spiro Site in Eastern Oklahoma}

The Spiro site is one of the major Caddo mound centers on the fringes of the Eastern Woodlands. This site is part of a much broader Caddo landscape that occupied Eastern Oklahoma, Western Arkansas, Northeast Texas, and Northwest Louisiana (Figure 1). The Caddospeaking people inhabited areas along many major drainages, such as the Little, Red, and Arkansas Rivers. Spiro was occupied by Caddo religious elites, but by the end of the fourteenth century, it was used primarily as a ceremonial center, which distinguishes itself from other mound centers in the Mississippian Southeast (Brown 1996; Rogers 2009). The site had major regional influences and maintained long-distance interactions (Rogers 2011) by exchanging important ritually-charged objects with complex iconographic elements, motifs, and themes, such as whelk shells, stone figurines, gorgets, and pottery.

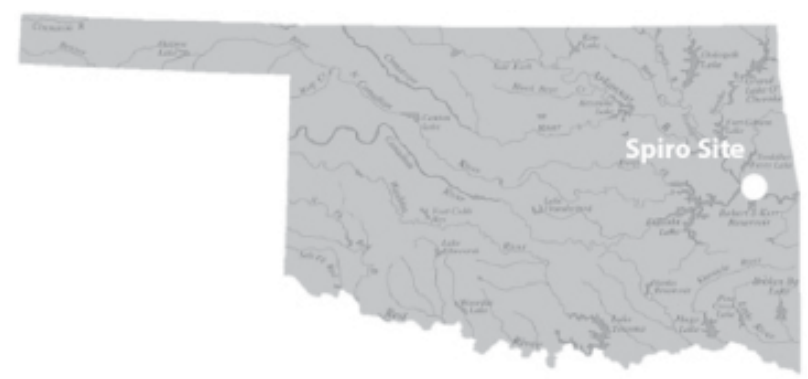

Figure 1. Location of Spiro site in eastern Oklahoma.

\section{The Craig Mound at Spiro}

Spiro was active as a major mound center for over five hundred years (ca. A.D. 900-1450) and continued well into the mid-seventeenth century as a mortuary. At the end of Spiro's occupation in the mid-fifteenth century, the Craig Mound was comprised of four cones, the largest of which contained several burials known as the Great Mortuary. A separate construction above the Great Mortuary is the well-known hollow central chamber or the Spirit Lodge (Figure 2). The placement of the Craig Mound artifacts and the different ways in which the burials were superimposed in the Great Mortuary represented the cosmological and iconographic complexity of these ancient groups (Brown 1996, 2012). As James A. Brown (2012:136) so elegantly noted, "the Great Mortuary and the totality of the main cone of the Craig Mound in this kind of scale becomes a ritual-architectural object of religious allurement." The Craig Mound was the "center of the universe" that brought together many different but socially linked pre-Columbian Caddo groups and their sacred objects. Thus, the Great Mortuary was not about personhood, but about the importance of the community as the whole. Moreover, the Spirit Lodge has been inferred to have been a separate episodic event that was constructed around A.D. 1450. This unique event seemed to be centered around one individual, who was buried with thousands of objects. Brown (2014) asserted that this one male individual was being transformed into a supernatural being. This narrative can be seen played out on dozens of engraved shell cups that were deposited with this individual. Thus, the act of constructing the Craig Mound and the placement of powerful objects represented the participants' "known universe in its geographical and cosmological dimensions" (Brown 2012:136-137).

\section{Using Ethnographic Analogies}

Meanings associated with prehistoric art forms are heavily drawn from colonial-period and other ethnographic sources. This information is then projected backwards through time and transposed onto the beliefs and actions of past peoples as a way in which to illuminate that past. The use of historical sources 


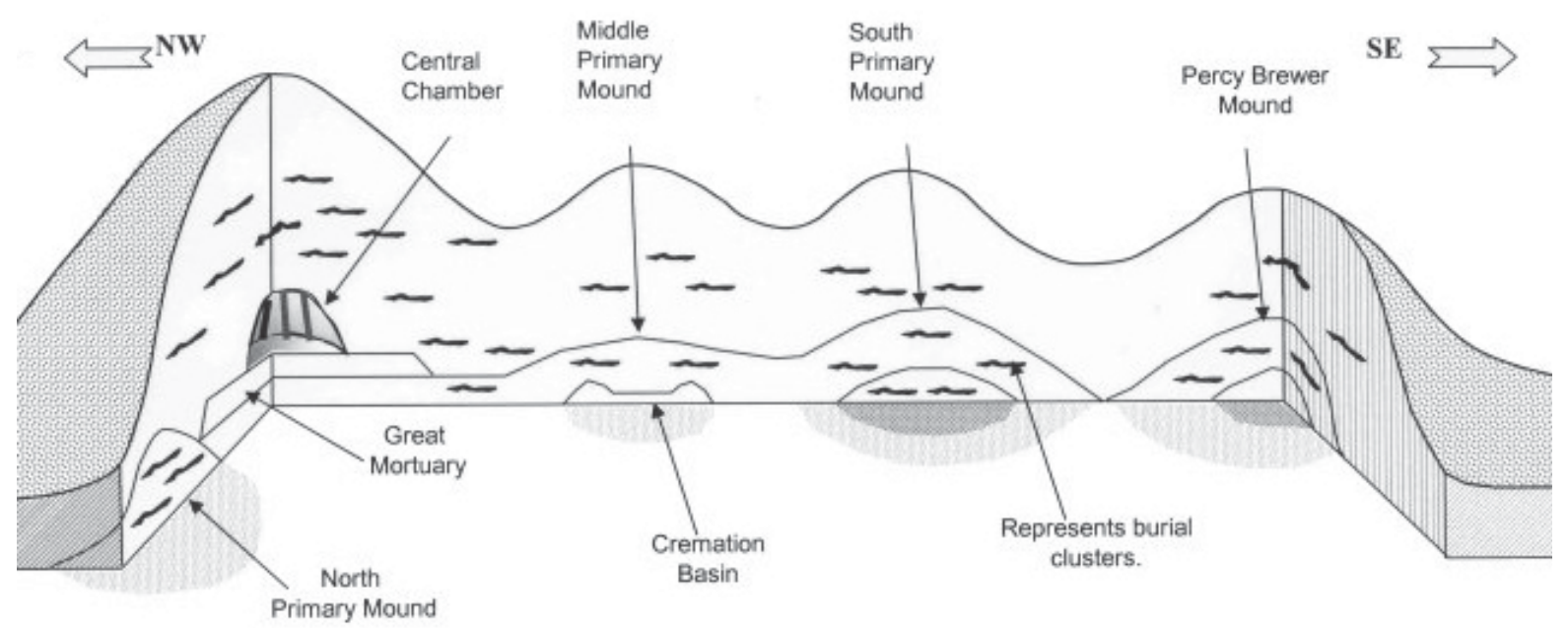

Figure 2. A 3D profile view of Craig Mound's four cones with their associated burials and location of the Great Mortuary and the Central Chamber (Spirit Lodge) (adapted from Merriam and Merriam 2004).

as a way in which to describe rituals and the religious beliefs of pre-Columbian groups has been fraught with acceptance and rejection over the past 50 years (Knight 2013). The advantages and disadvantages became the catalyst by which art historians, iconographers, and archaeologists argued over how to interpret ancient representational images. For instance, the famous Mayan iconographer George Kubler (1969:48) once wrote:

However lucid they may be, foreign texts of late date should not be forced to explain matter beyond their own scope without painstaking calibrations. When Thomas Aquinas explained Aristotle, he explains his own mind more than the Stagyrite's. When Sahagun codified the reports of many Aztecs informants, they were no more concerned with classic Maya life than St. Thomas was with pharaonic Egypt.

Therefore, we should be mindful of the variety of sources that can be used to interpret the past and, when used, to acknowledge their explanatory pitfalls. Despite this methodological division in conjunction with the inherent limitations of the archaeological record, ethnographic sources are still commonly used as references for interpreting pre-Columbian imagery. Iconographers have agreed to take a more middle-ranged approach when it comes to ethnographic analogies. No more are claims made that the past and present are continuous and static belief systems. Ethnographic analogies have much utility and can be viewed as complimentary to the archaeological record. All in all, are not most things that archaeologists do analogies in themselves? The utility for using more contemporary indigenous groups who most likely had a relationship to the past peoples in which archaeologists show interest is significant and should not be ignored. As Knight (2013:232) stated, "In iconography, all talk of cultural models, of systems of beliefs, of mythic referents, of communities, of artisans, of elites, and of ritual is thoroughly grounded in ethnographically framed possibilities." If we want to study iconography it would be almost impossible to take off the ethnographic tool from our methodological tool belt. For this study, I draw on ethnographic resources concerning several early historic tribes that resided in the Southeast and surrounding areas. Their origin narratives are very similar and consequently are used to make interpretive sense of the iconography found in the Craig Mound burials.

\section{Creation of the Cosmos: An Ethnographic Perspective}

Studying iconography has three faces: what we know, what we think we know, and what we do not know. Iconographic research of pre-Columbian groups without written histories has unique challenges, but it 
is still possible to reveal meanings behind the images that were depicted on shell, copper, stone, and pottery (Lankford 2011). Iconography is the "relation of their imagery to their ritual referents" (Knight 2013:4). Over thousands of years, humans have embedded into art the communication of ideas, ranging from the mundane to the supernatural. The art belonging to ancient societies in North America possess no accompanying texts with which to compare, however, and there is no "set in stone" method for interpreting them. Nevertheless, attempts to interpret North American iconography have only gained fervor in the last decade (See Knight 2013; Lankford 2011; Lankford et al. 2011; Reilly and Garber 2007). Studying the iconography that is depicted on Craig Mound ceramics offer up other challenges, but it is nonetheless an important way in which we can expand our understanding of the Caddo and Mississippian worlds.

In the beginning of the cosmological formation, before any humans were created, air, water, and earth were the only elements that existed. These elements were divided by several different spiritual powers or beings. According to southern Siouan speakers (e.g., Kaw, Omaha, Osage, Ponca, and Quapaw) this power was known as Wa-Kon-Da. This entity could not be seen and did not make any sounds, and yet it transcended through all known worlds and helped to create male and female life forces (Bailey 1995:30-31; Fletcher and LaFlesche 1911:597-599; Howard 1965:99). The Pawnee also had a very similar creative force called Tirawa. This being created all things according to early Pawnee accounts (Dorsey 1904:3). Under Tirawa, there were semi-gods that were associated with the sun, moon, and various stars. Tirawa positioned the sun, moon, and the stars into specific places in the cosmos. The sun is usually personified as a male, while the moon is usually personified as a female, apart from the beliefs of the Tunica tribe. Morning Star, an incredibly important spiritual figure in most Southeast tribes, had control over the gods: Cloud, Wind, Lightning, and Thunder. The west is indicative of Morning Star's existence. Finally, Tirawa commanded all the gods to smack the water to separate it from the earth, and they subsequently sang and danced the worlds into existence. Once these worlds came into existence, specific animals played an important role, such as elk (Osage), crawfish and bears
(Creeks), and hawks (Caddo) to help to uphold the cosmological balance (Swanton 1929).

Complex representational imagery was one of the main mediums by which individuals and other groups accessed ritual knowledge to create and manipulate their cosmological worlds (Dye 2012). The organization of their cosmological worlds was based on opposing layers, which created a tri-level cosmology. Because of several scholars' past work efforts, several locatives or visual keys to identify specific religious and ritual narratives have been identified that express each cosmological layer (Reilly 2004; Reilly and Garber 2007). The layers include "the bottom layer, or the beneath world, that comprised a vast body of water [as well as underwater creatures], whereas the above world included the majestic expanse of the sky. The middle world lay between the bound and opposing forces of the beneath world and the upper world" (Dye 2012:142). The Below World was thus seen as the counterpart of the Above World, very chaotic and used by destructive forces (Hudson 1976:122-132).

The sun and flying creatures characterize the Above World, whereas humans, plants, and animals characterize the Middle World (Lankford 2011; Reilly et al. 2007). "This notation expresses the tension of the natural balanced against the supernatural, or of the Above World poised against the Beneath World" (Reilly 2004:127). In other words, the Caddo peoples who resided in the middle world were in a constant battle to keep the two opposing worlds in balance. One way religious elites wielded sacred power to balance opposing worlds was adorning motifs on copper, shell, and pottery. Essentially, "their [cosmological worlds] were a set of contradictions, which had to be stabilized through ritual propitiation and iconographic representation" (Reilly 2004:126).

\section{Addressing the Cosmological Significance of a Pot}

Iconographic research in the Southeast has primarily emphasized images that are depicted on marine shell, copper, textiles, and stone (Brown 2012; Horton 2010; Phillips and Brown 1978; Reilly and Garber 2007). Late prehistoric (A.D. 950-1600) societies in the North American Southeast has yielded copious 
amounts of this distinctive material culture, which have a wide spectrum of geometric shapes, supernatural and natural animals, people, and cultural heroes, all of which provide glimpses into cosmological ideologies. The pervasive adoption of these materials and iconography across the Southeast has been referred to as the Southern Cult, the Southeastern Ceremonial Complex (SECC), Southeastern Interaction Sphere, Mississippian Iconographic Interaction Sphere (MIIS), and Mississippian Ideological Interaction Sphere (Reilly 2004; Knight et al. 2001; Waring and Holder 1945). However, since the 1940s, iconography depicted on ceramics has not been regarded as an integral part of this sacra. Ceramics, therefore, are frequently dismissed from being associated with a ceremonial complex (Dowd 2011).

Archaeologists routinely regard Caddo ceramics as merely containers with some ritual attributes, such as their placement within burials or on-mound contexts, but disassociate their relationships to other representational art forms because of their ubiquity in the archaeological record and their deposition in domestic contexts. In this vein, ceramics are stigmatized as not unique enough for iconographic research. However, in the Caddo region, ceramic vessels are associated with other material types that have more highly visible anthropomorphic and zoomorphic imagery.

Archaeologists have performed iconographic methods to understand the imagery on ceramic vessels. These types of studies emphasized the roles of pottery in understanding Caddo ritual activities and the different people who had access to their power (Blitz 1993; Dye 2011; Lambert 2014; Pauketat 1989, 2013; Pauketat and Emerson 1991; Rees 1997). Pauketat and Emerson (1991) concentrated on examining how ceramics reflect the cosmological structure of pre-Columbian Native North Americans. They discovered that Ramey Incised vessels, made by Cahokia potters, were coiled and decorated to maintain cosmological stability as well as reaffirm the ideologies of ritual elites (Figure 3). But the fact remains that ceramics with complex elements, motifs, and themes are still viewed as watered-down versions when compared to "finer-made" materials, like stone maces, engraved whelk shells, shell gorgets, or copper plates.

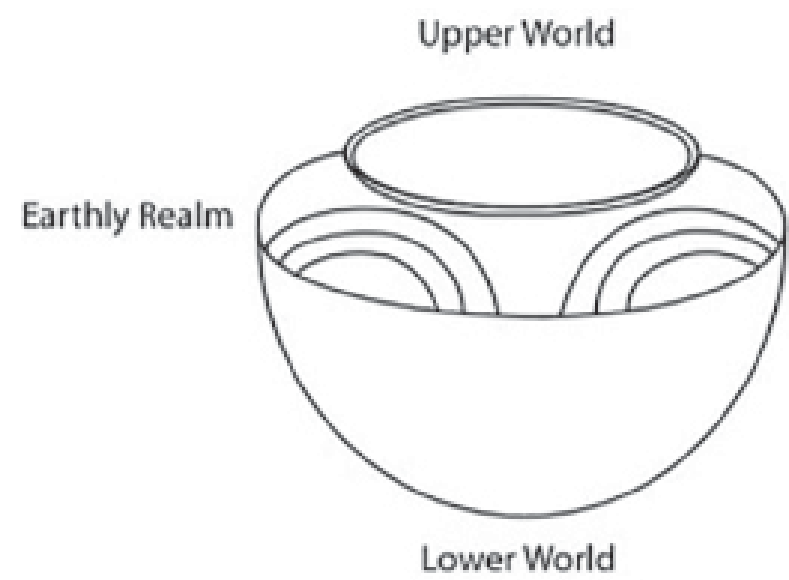

Figure 3. Ramey Incised pot from Cahokia representing the Mississippian cosmos (adapted from Pauketat and Emerson 1991: Figure 11).

Iconographic research into ceramics has gained some momentum in the last five years. Phillips (2012) studied Hemphill Engraved style pottery found at the Moundville site in Alabama. While Phillips (2012:98) "avoided iconographic meaning in favor of style," she did compare the meaningful referents of the motifs to different economic models. Phillips' findings suggested that these motifs fit best with an Association Model whereby there are discrete separations between iconographic themes in different contexts.

In recent years, Caddo archaeologists have spent a lot of time interpreting the meanings of ceramic imagery. For instance, Fields and Gadus (2012) and Gadus (2013) explored the structural similarities in Late Caddo Ripley Engraved motifs on bottles. To make sense of the abstract motifs on the bottles, they compared them with more representational imagery found on shell gorgets and shell cups from mound sites in Texas and Oklahoma. Their findings indicated that ceramic motifs expressed lower and upper world imagery as well as highlighted the importance on how vessel forms play an important role when considering the overall iconographic significance (Fields and Gadus 2012; Gadus 2013). Nash (2017a, 2017b) studied the iconography and distribution of Avery Engraved vessels. Her findings suggest that not only do Avery Engraved vessels portray locatives to the celestial Upper World, but also portray locatives of the Beneath World. Dowd (2012) studied the widespread adoption of reptilian imagery in Late prehistoric Caddo communities. She hypothesized that the variety of reptilian imagery, 
such as frogs and snakes adorned on ceramics, were localized manifestations of similar Below World narratives. Lankford (2014) conducted an interregional comparison of ceramic imagery and ceramic paste with more representational imagery found on southeastern shell engravings and southwestern cave paintings to understand the extent to which Datura cult ideologies influenced the Caddo region and beyond. Hart and Perttula (2010) studied the ceramic imagery from a double burial from the Washington Square Mound site in northeast Texas. The authors believed that rattlesnake as well as other iconographic themes were regional variations associated with broader themes from the Southeastern Ceremonial Complex.

McKinnon $(2013,2015,2016)$ has been a major figure in trying to understand the meanings of Caddo iconography on multiple scales of analysis. McKinnon (2013) wrote an intriguing article, which viewed Caddo landscapes as their own ritual object that can be studied in relation to the organization of settlements and distribution of materials. In other words, Caddo landscapes have an ontological relationship between the people and objects who live on and modify them through time and space. Ceramic vessels are literally made from what I believe to be a part of McKinnon's notion of ritual landscapes. These two objects are so closely related (i.e., permanent versus portable landscapes), that a study of their relationships would make for an excellent research topic. He also used a GIS approach to understand the large-scale distribution of the rayed circle motifs on whole Caddo vessels. McKinnon discovered that the distribution of the rayed circle overhead motif is much more dispersed and widely shared, while the rayed circle burst motif is more clustered and restricted to certain river drainages (see McKinnon 2016, Figures 6 and 7).

Since the discovery of the Great Mortuary and the Spirit Lodge in the Craig Mound at the Spiro site, ceramic studies have been limited to petrographic, chemical, and stylistic studies (Brown 2012; Early 2012). As a result, finely-made ceramics with complex iconography have been seriously understudied. Iconographic studies into pottery are necessary to obtain a better understanding of cosmology and the ritual activities that maintained those narratives. The guiding premise of this paper is that the ceramics found in ceremonial contexts in the Craig Mound is an assemblage of forms and meaningful imagery created for ritual use and perhaps to illustrate specific cosmological narratives.

\section{Methodology: Iconographic Comparisons and Analysis}

In the last 10 years, iconographic studies have advanced the interpretive value of the archaeological record. We are now able to breakdown a complex representational image, understand each motif and its relationship to one another, and then reconstruct the image to develop a much more nuanced narrative of the past. Iconographic studies go beyond the identification of what is depicted on specific objects, such as an anthropomorphic figure with wings. Rather, this method seeks to explore deeper understandings of the cultural significance of the depiction, such as "does it resonate an identifiable motif or theme that carries information about the cultural milieu in which it was produced" (Knight 2013). An example is the well-known Craig style of two anthropomorphic figures depicted on either side of a pole, also known as the axis mundi (Figure 4). At first glance, the two figures look like they are standing idly beside the pole. However, as Reilly $(2004,2007)$ has asserted, perhaps pre-Columbian compositions were not supposed to be understood in a two-dimensional state. Instead, once we deconstruct each motif and reconstruct the series of motifs in a three-dimensional

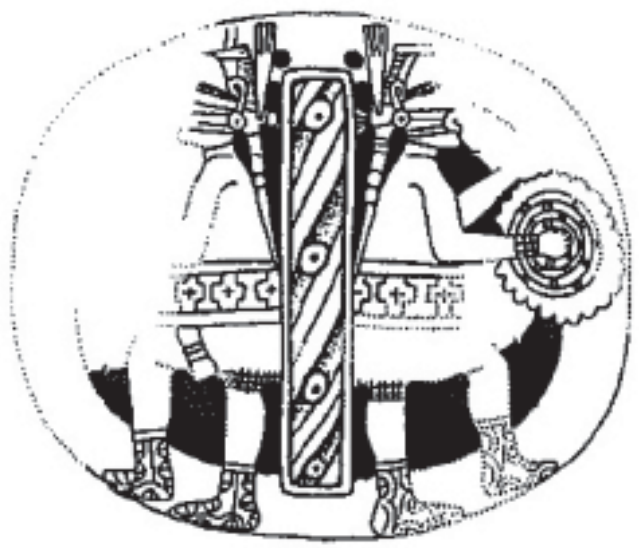

Figure 4. Craig Style Gorget from the Craig Mound (adapted from Reilly 2007:Figure 3.1). 


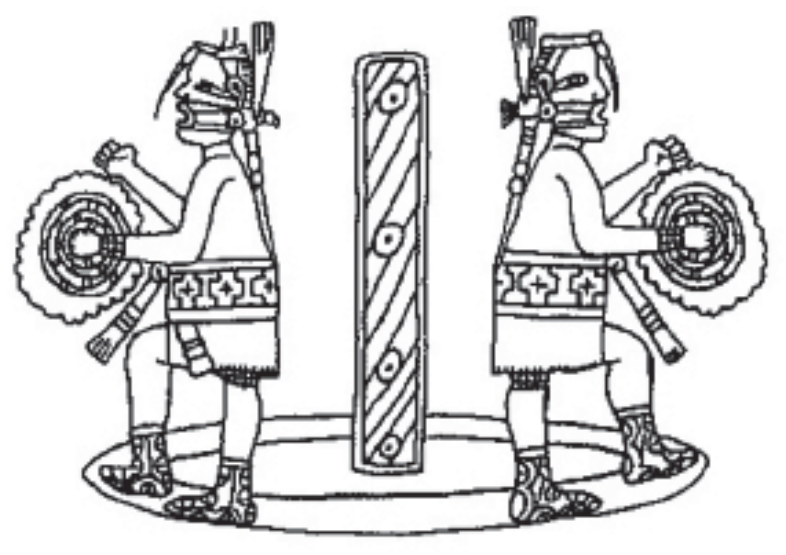

Figure 5. 3D reconstruction of a Craig Style Gorget from the Craig Mound (adapted from Reilly 2007:Figure 3.1).

style, it is understood that the gorget portrays two anthropomorphic figures dancing around the axis mundi (Figure 5). The shell beneath their feet would then be a locative of the underworld while the axis mundi would be the locative of the Above World.

In this paper, I analyzed 98 ceramic vessels from Craig Mound burials. Specifically, I used a unique composite vessel that was recovered in one of the Craig Mound burials, which depicts the iconography of each cosmological world (Lambert 2014). I utilized this one vessel as a kind of "Rosetta Stone" to help decipher the iconographic grammar of other ceramics in Craig Mound burials. I also use highly visible representational imagery on shell cups and shell gorgets to help decipher the more abstract curvilinear and rectilinear motifs on pottery. As mentioned earlier, I only concentrated on the burials that were not associated with the Great Mortuary or the Spirit Lodge; the reasons for this will become apparent in the discussion section below. I dated each burial with their associated materials. As a result, I assigned the burials to four different periods: Spiro I, Spiro II, Spiro III, and Spiro IV. Finally, I arranged the ceramics that depicted different cosmological worlds in time and space to identify patterns in the data. Ultimately, what this methodology demonstrates is that pre-Columbian representational images from Spiro have the potential to convey larger cultural, social, and historical narratives that not only reflect the producers of the imagery, but also its association within the broader community. Also, this approach highlights the importance of using ceramics in iconographic research because of their cultural significance to the Craig mound participants.

\section{Craig Mound Motifs and Their Meanings}

I used a four-step approach to study iconography on Craig Mound ceramics. This approach was developed and outlined by Knight (2013), Kubler (1962), and Straten (1994). I also took the composition, themes, and styles that Phillips and Brown (1978) used to create iconographic meanings with Spiro shell engravings. I first tried to identify sequences, elements, motifs, and compositions that were found on a complex composite vessel and ended with attempting to infer the underlying principles that linked those motifs to other Craig Mound ceramics. By element, I am referring to basic lines and shapes that are brought together by the producer to create a motif. By motif, I am referring to individual anthropomorphic, zoomorphic, or geometric figures that are a set of elements which creates the identifiable representational image. By composition, I am referring to an amalgam of elements and motifs that were used to create a specific narrative or theme. By sequence, I am referring to a set of similar compositions that are expressing the same theme.

\section{Iconographic Meaning of the Composite Vessel}

Figure 6 represents a complex composite vessel, but it also reveals combinations of Caddo motifs that have never been seen together on a ceramic pot in the Arkansas Basin. Thus, it is feasible that the rarity of this pot will help translate other Craig Mound ceramics with similar iconography. This vessel is a composite Caddo ceramic form, and my assertion here is that the vessel has embodied a three-dimensional representation of the Caddo peoples' three-level cosmological configuration.

First, the vessel's form is just as important as its iconography. Starting from the bottom-up, the vessel is a bowl, turns into a jar, and finally, the top becomes a bottle. The vessel's decorative composition is separated into three components, and the segments are engraved with three very distinct motifs. The skilled potter(s) who coiled and decorated this vessel likely joined together these three vessel forms to create three separate 

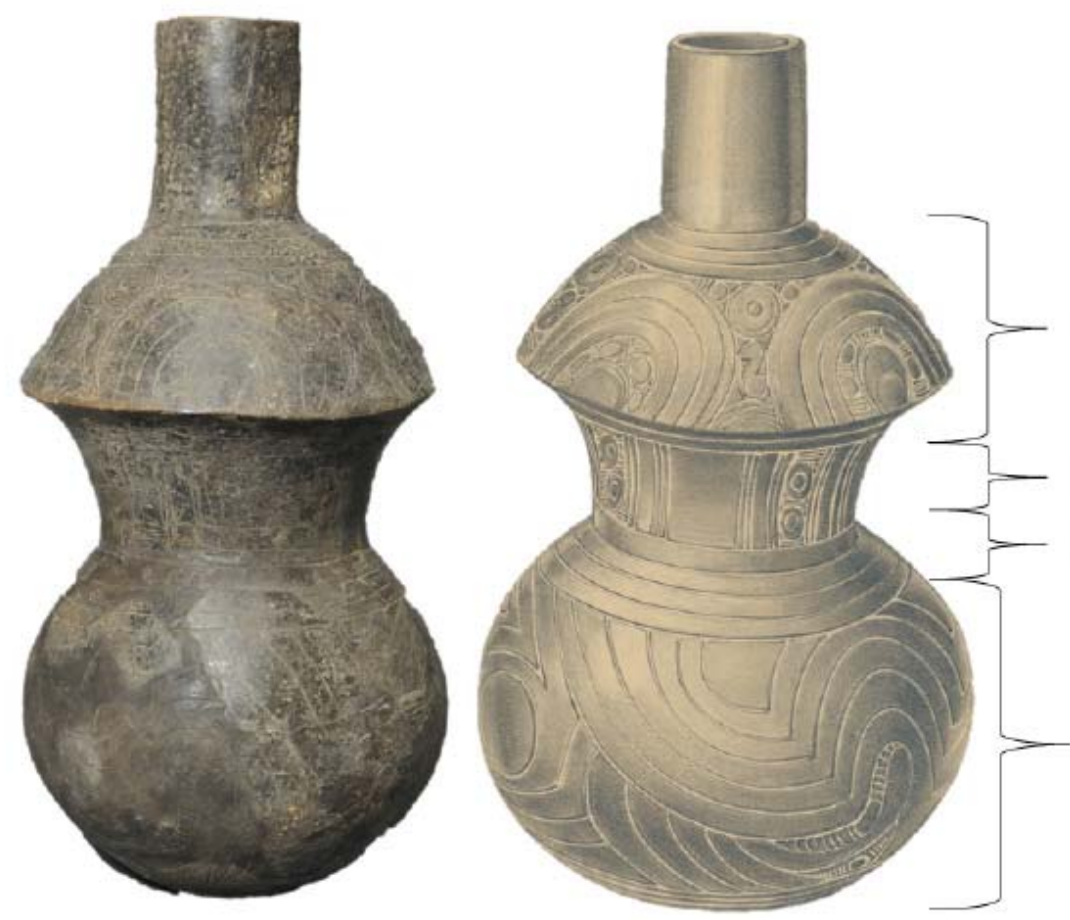

Above World

Axis Mundi

Middle World

Below World

Figure 6. Left: Complex composites vessel from Burial 7 in the Craig Mound; Right, WPA artifact illustration depicting the very complex composite bottle with engraved motifs referencing the axis mundi and the Above, Middle, and Below Worlds.

sections on which to convey their cosmological worlds. Observing the vessel's profile, we can see that the bottom or "bowl" portion is a Spiro Engraved motif with other iconographic elements which signifies the Below and Middle worlds.

The lower half of the bowl portion is very water-like with underwater creatures (perhaps underwater serpents?) swimming between the Below and Middle worlds. This is most likely a reference to the Below World. The upper half of the bowl portion has four pedals or "quatrefoils" that are positioned in the cardinal directions and these four lobes are resting or floating on top of the watery underworld. This is most likely a reference to the Middle World. The iconography on the middle section or the "jar" portion of the vessel is clearly referencing the striped pole, sacred tree, or the axis mundi, which connects the Below and the Above worlds. Other depictions of the axis mundi are commonly found on shell gorgets and copper plates. It is also interesting to note that the engraved lines beneath the sacred pole could be indicative of the ceremonial dance circle, which has also been displayed on other engraved shell gorgets from the Craig Mound (Reilly
2004). Lastly, the iconography on the upper or "bottle" portion of the vessel is perhaps the most complex of the three motifs. I do not think many would argue against the notion that this portion is showcasing the intricacies of the sky. There are concentric rayed circles going all around the vessel. These types of motifs are considered references to the Above World, yet there are other iconographic elements here that need further study.

What makes this vessel even more remarkable is that not only can one observe the three worlds and the axis mundi on its profile, but all three cosmological worlds and the axis mundi can be viewed in plan view (Figure 7). From this viewpoint, the axis mundi on the jar portion disappears, but reappears as the opening of the vessel's orifice. It is as if the maker of this vessel wanted or needed to view the three worlds and the axis mundi from all angles. This would especially be the case if participants poured a liquid into the vessel and drank from it. As they raised the vessel, the three worlds and axis mundi would come into view again. A ritually charged liquid, such as the Black Drink (e.g., Crown et al. 2012), passing through the three worlds and being consumed individually or communally would have 


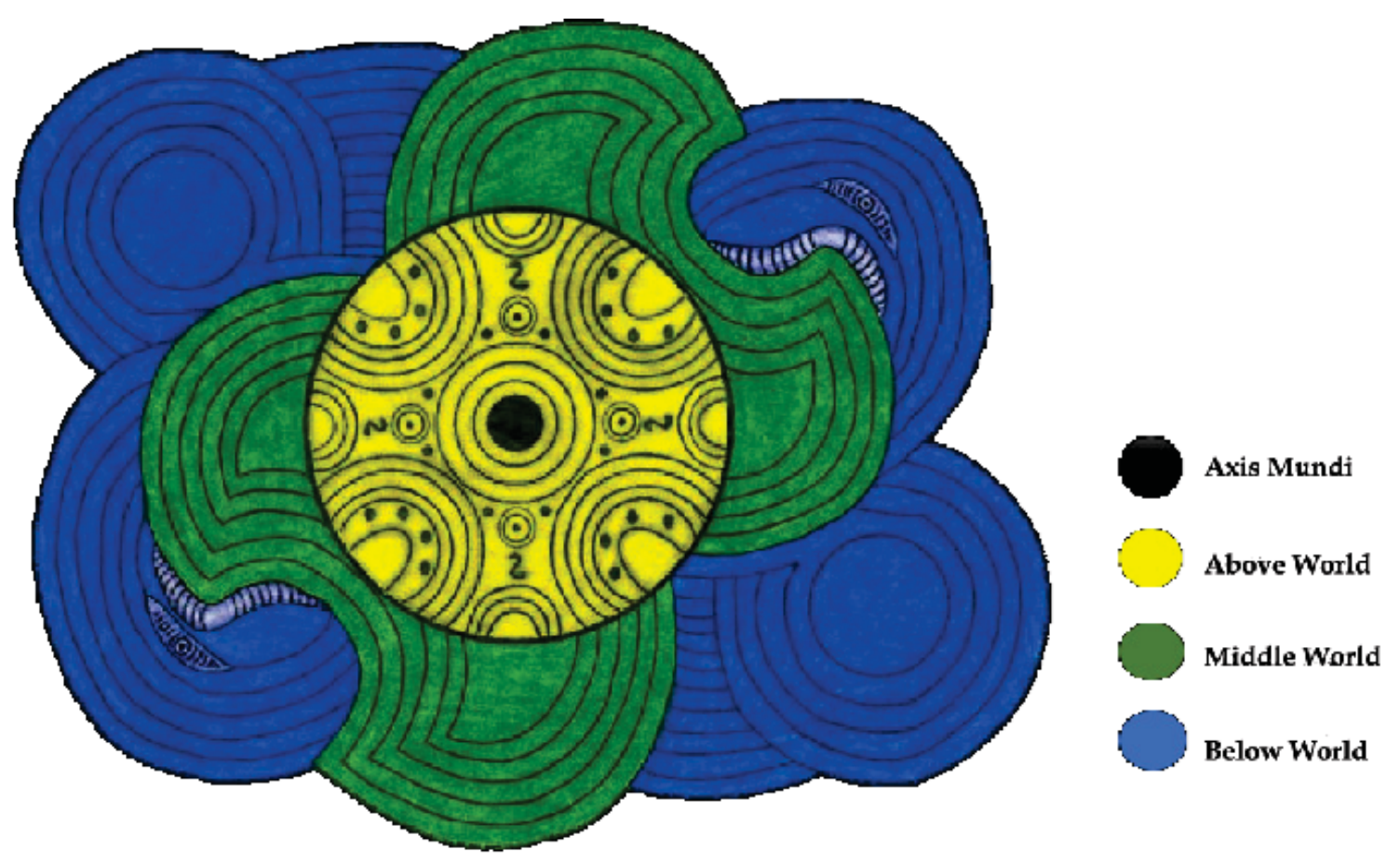

Figure 7. A plan view or an above view of the composite vessel's iconography.

had powerful religious meanings. It may be that many different Craig Mound participants came together and represented their cosmological worlds on this vessel. The fact that this vessel was recovered from a burial in northeast corner of the Craig Mound further supports this claim.

\section{Deciphering other Craig Mound Burials}

I studied the iconography of all pottery vessels from the Craig Mound that were not associated with the Great Mortuary or the Spirit Lodge. I used the composite vessel mentioned above as a kind of tool to decipher iconographic grammar and locate similar motifs, elements, and themes on other Craig Mound vessels. The bottom portion or the "bowl" segment is clearly a Spiro Engraved motif. Spiro Engraved bottles always depict "watery" motifs that have been interpreted in the past as a locative of the underworld (Lambert 2014). This is also strengthened by the strong possibility that ritually charged liquids most likely were contained within the bottles. Therefore, I first examined each Craig Mound Burial to identify Spiro Engraved bottles. Of the 98 burials that were examined, 14 burials contained a total of 18 Spiro Engraved bottles. It is important to note that all 14 burials that contained Below World iconography did not contain any Above World iconography. For each individual burial that contained Spiro Engraved vessels, there may have been a rule in place whereby people could not enter another cosmological realm. Lastly, and probably the most intriguing finding is that all burials that contained Below World iconography were restricted to the southeast portion of the Craig Mound.

The middle portion or the "jar" segment of the composite vessel clearly shows the axis mundi in the four cardinal directions. I assert that the composition on Crockett Curvilinear Incised vessels is depicting the axis mundi. When the design is rolled out, it bears a remarkable resemblance to the axis mundi on shell gorgets and shell cups (Figure 8). Unfortunately, all but one Crocket Curvilinear Incised vessel recovered from the Craig Mound are from significantly disturbed contexts. Thus, I was unable to match most of the vessels with their associated burials. Yet, it is intriguing nonetheless that the one Crocket Curvilinear Incised vessel (Burial 66) was in the very center of all the Craig Mound burials. Of course, this is completely speculative now but should still merit some consideration when other meaningful patterns emerge. 


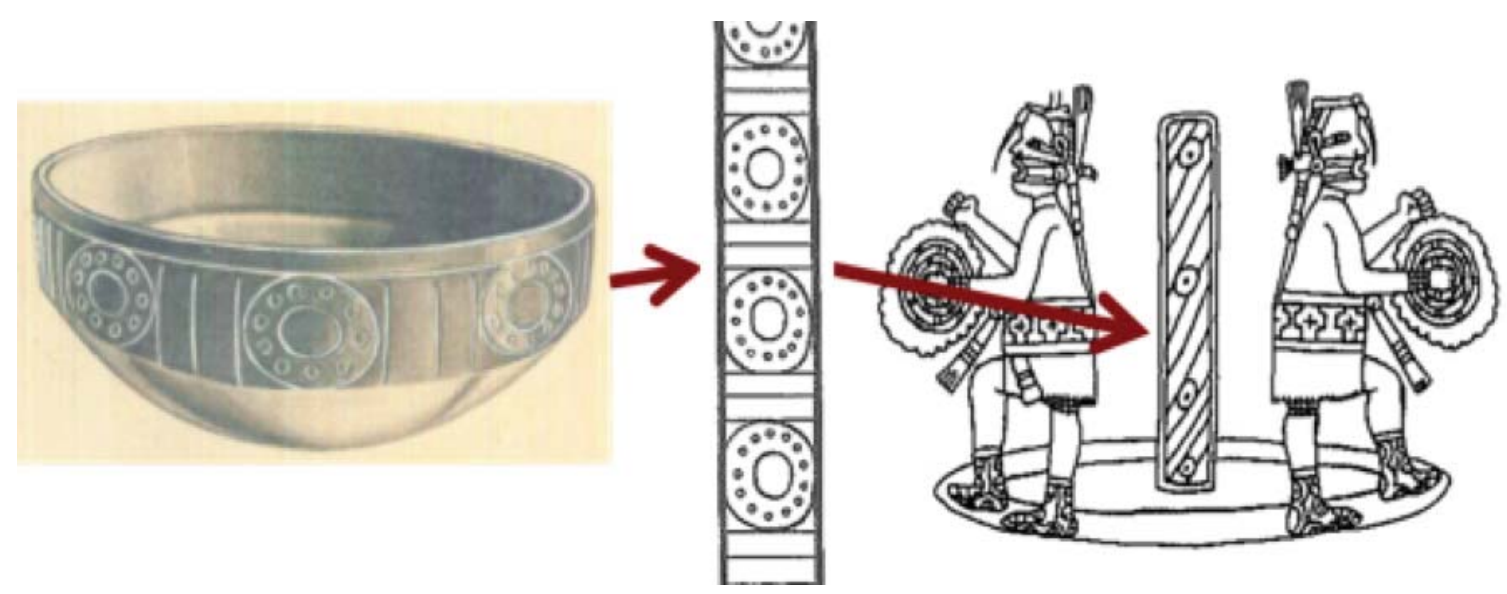

Figure 8. Illustration of a Crockett Curvilinear Incised vessel from the Craig Mound (left); roll out of the vessel's design (middle); and vessel rollout looks very similar to axis mundi's found on shell gorgets (right).

The upper portion or the "bottle" segment of the composite vessel clearly shows the details of the Above World. The concentric ray motifs create a distinctive composition that has been theorized in the past as locatives of the Above World (Phillips and Brown 1978). There are also what could be abstract flying creatures between the rays. Birds or raptors, such as hawks as well as flying serpents, have also been theorized in the past as references to the Above World (Reilly 2007). Thus, ceramics in other Craig Mound burials that have similar compositions can be hypothesized as indicative of the Above World. Out of the 98 burials analyzed, eight burials (and nine vessels) contained ceramics with Above World iconography. Interestingly, all the Above World ceramics were depicted on jars, and just like the Spiro Engraved bottles, no Below World iconography was found with the Above World burials. Furthermore, burials with Above World iconography are only recovered in the northwest corner of the Craig Mound. All the ceramic types that have Above World iconography are Avery Engraved and Sanders Engraved (Figure 9). Spiro Engraved is the only ceramic type that has Below World imagery (Figure 10).

\section{Results of the Analysis}

The analysis of the Craig Mound vessels has shown the importance of individuals to be buried with artifacts conveying a specific cosmological world, but each cosmological world had to be depicted on separate vessel forms that includes Below World (only bottles),
Middle World (only bowls and carinated bowls), and Above World (only jars). All things considered, it appears there were defined spaces in the Craig Mound in which individuals that signified a specific celestial realm could be placed.

Now that there is a good understanding of what the ceramic imagery signifies, it is time to see if there are patterns in the Craig Mound burials through time, from Spiro I through Spiro IV periods, to understand the history and creation of Craig Mound's cosmological structure.

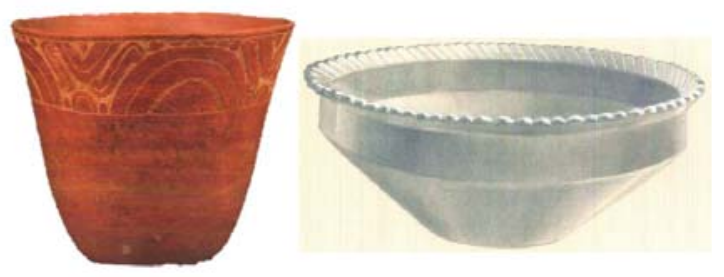

Figure 9. Examples of Above World iconography on vessels: Avery Engraved (left) and Sanders Engraved (right).

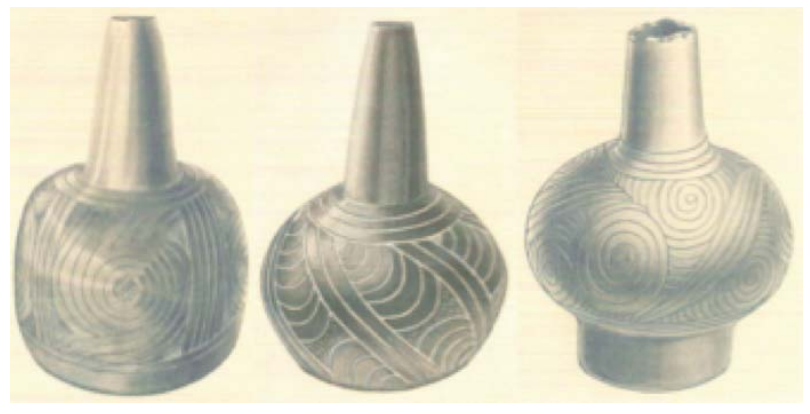

Figure 10. Examples of Below World iconography on Craig Mound ceramics, Spiro Engraved. 


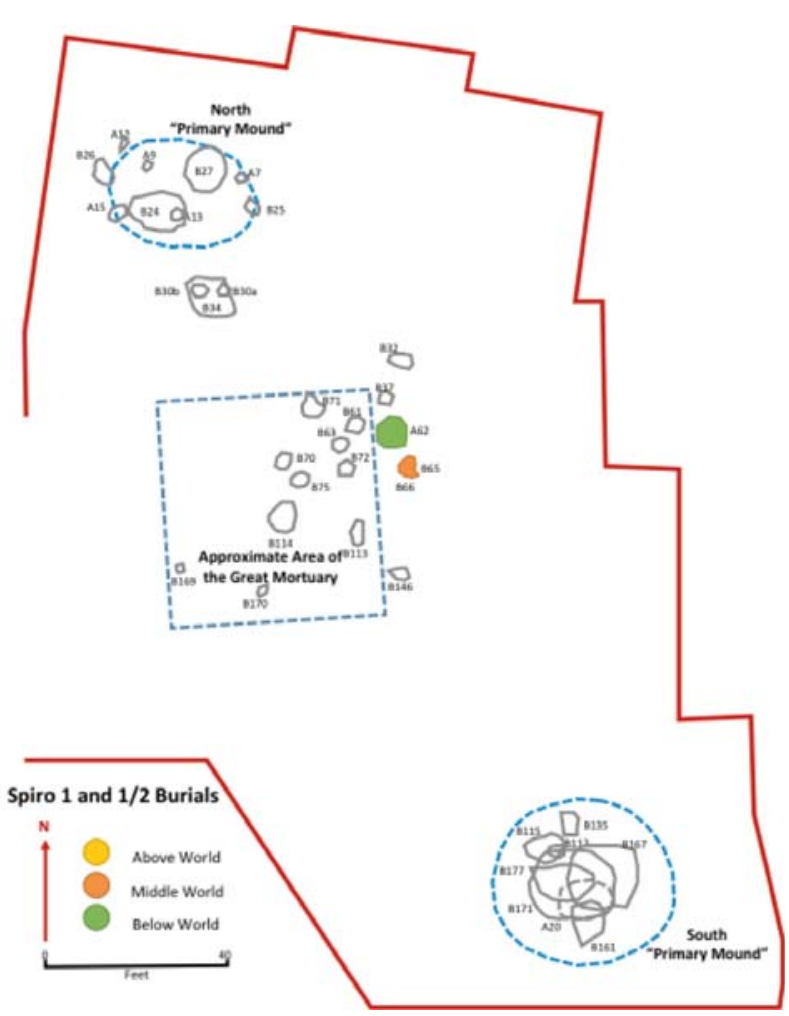

Figure 11. Craig Mound burials from Spiro I and I/II periods.

Thirty-four burials date to the Spiro I and I/II phase, ca. A.D. 1000-1100 (Figure 11). In this period, there are only two ceramic vessels that have iconography, one Spiro Engraved bottle and one Crockett Curvilinear Incised bowl. No Above World iconography was present in the Spiro I burials. Therefore, as shown in Figure 11, there does not seem to be any cosmological structure regarding the use of ceramics. However, this period had the earliest burials and perhaps Craig Mound participants were still negotiating how to (re)create their cosmos through burying their dead.

By Spiro II and II/III periods, ca. A.D. 11001250, a pattern has started to emerge (Figure 12).

Twenty-six burials dates to the Spiro II period, and as shown in Figure 12, there are ceramic vessels present that suggest Above and Below Worlds. Burials 82 and 170 have Avery Engraved and Sanders Engraved vessels and are placed in a northwestern direction. Both burials 182 and 189 have Spiro Engraved bottles $(n=7)$ and are oriented in a southeastern direction. During this period, a cosmological structure may be developing due to the separation of ceramic vessels with Above World and Below World imagery.

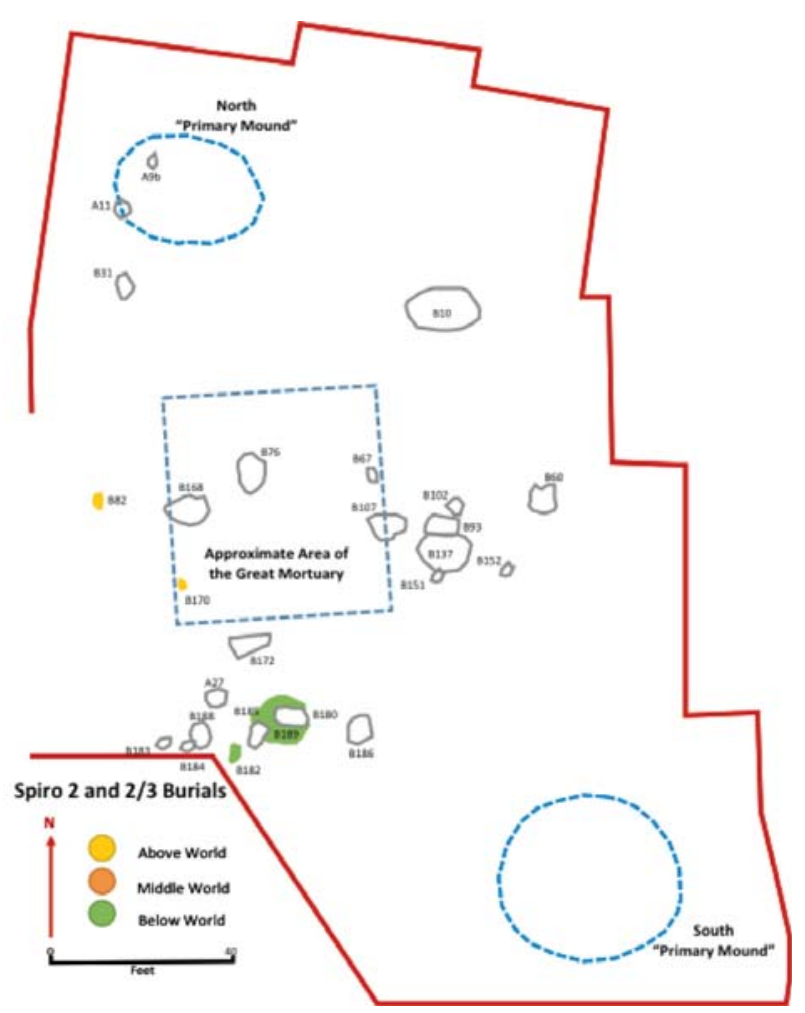

Figure 12. Craig Mound burials from Spiro II and II/III periods.

By the Spiro III and III/IV periods, ca. A.D. 1250-1400, a stronger pattern emerges that may signify a cosmological structure. There is a significant increase in the number of burials and the quantity of ceramics that have Above and Below World imagery (Figure 13). It is in this period that the complex composite pot (Burial 7) that depicts all three cosmological worlds was buried in the Craig Mound. This pot was buried in the far northeast corner of the Craig Mound, and perhaps used create the cosmological ordering of the burials. This could be why there is such a large increase in burials with Above and Below World iconography: 42 burials comprise Spiro III and III/IV burials. Seven burials (B7, B3/4, B29, A18, B50, B36, and B64) all contained Above World ceramic jars. The ceramic types include Sanders Engraved and Avery Engraved. It would be interesting to use INAA or other types of compositional analyses to understand from where these vessels were made. Are they non-local vessels being represented here and whose iconography is being depicted - communities living around Spiro or imported from southern Caddo communities? Just like the Spiro II and II/III periods, Above World burials were only found in the northern part of the Craig Mound. Ten burials (B100, A25, B88, 


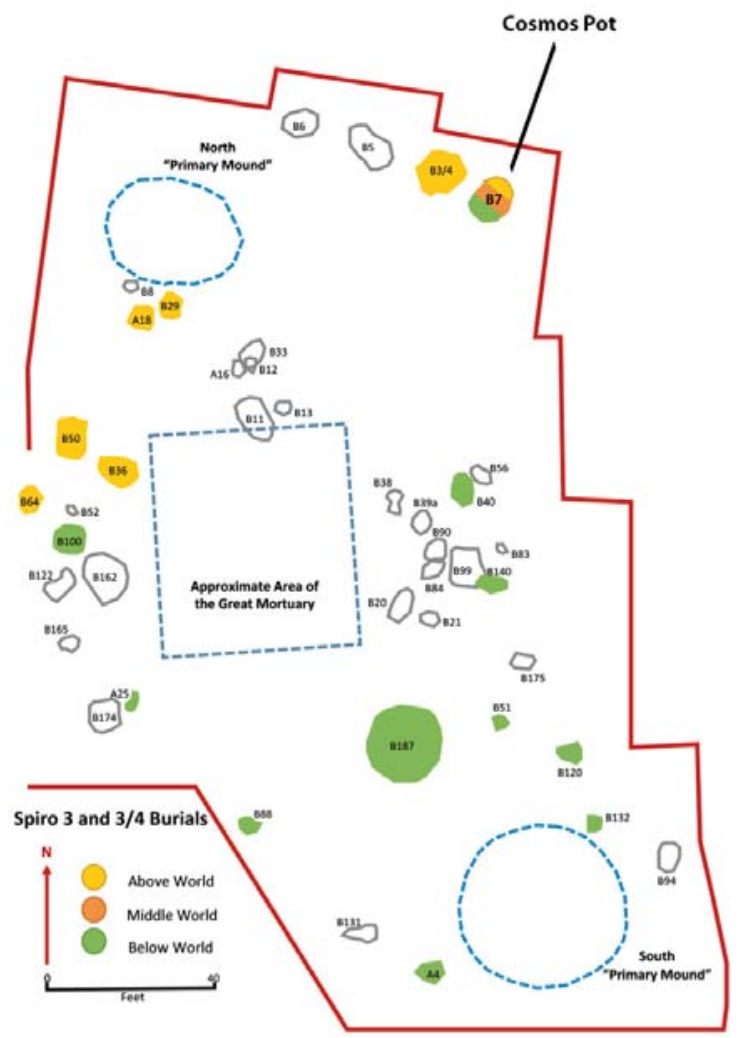

Figure 13. Craig Mound Burials from the Spiro 3 - 3/4 periods.

A4, B187, B51, B120, B132, B140, and B40) all contain Below World Spiro Engraved bottles. Just like the Spiro II and II/III periods, Below World bottles were only found in the southern portion of the Craig Mound.

\section{Discussion: Looking for Cosmological Structure in Craig Mound Burials}

In this paper, I have used the word ritual several times. Therefore, it is important that I define this term to understand data I am observing. For the Caddo peoples, ritualism and access to other celestial worlds was a tangible process that was interwoven into their daily, social, political, and economic life (Miller 1996). It was embedded in their subsistence, agriculture, hunting, and technologies. Ritual practices were expressed from pole-setting to constructing whole villages. Thus, I consider Caddo ritual as "a heightened awareness [and expression] of interconnectedness and the relations between things" (Fowles 2013:103) as other Caddo archaeologists have theorized (Perttula 2017). I view Caddo rituals as "in the moment" social practices that brought people, things, and the cosmos together. Rituals then can be defined as the actions by people, things, and the cosmos. Rituals are the actions that construct, create, and modify religious beliefs. During rituals, people can remember, forget, accept, deny, or alter their beliefs (Fogelin 2007, 2008). Rituals are also materially expressed through embodied practices of people (Joyce 2012). In this view, ritual is also seen as an active practice that is made routine and constantly negotiated within a social collective. This study has examined many Caddo burials in the Craig Mound. It is reasonable to assume that during these ritually amplified events of burying the dead with meaningful objects they too were expressions of a similar Caddo worldview that promoted a sense of interconnectedness between people, places, and things.

It has been argued that the ways in which the Caddo organized themselves and their objects spatially and temporally was significantly interwoven into how their cosmos was also structured. Kay and Sabo (2006) extensively studied Formative and Early Caddo period (A.D. 850-1150) charnel houses. Charnel houses had extended entranceways. They are viewed as special places by which ritual elites processed and stored the dead. Their analysis revealed that charnel houses had a specific southward orientation. For the Caddo, important places and objects positioned in a southward direction had symbolic meanings to death, renewal, and the way to the path of souls where spirits ventured into the Below World. Brown (2012) has been the premier archaeologist to research the Great Mortuary in the Craig Mound. The Great Mortuary was a massive episodic burial event comprised of several litter burials and ritually charged objects. Brown studied the placement of these important objects in relation to the burials and cardinal directions. He surmised the Great Mortuary as a cosmogram or tableau, whereby ritual elites drew cosmological power from through the placement of objects in certain cardinal and semicardinal directions. Furthermore, Sabo (2012) compared a seventeenth century Spanish map, called the Teran map that illustrated a large Nasoni Caddo village along the Red River in East Texas, with how the Caddo people structured their cosmos. He discovered that the ways 


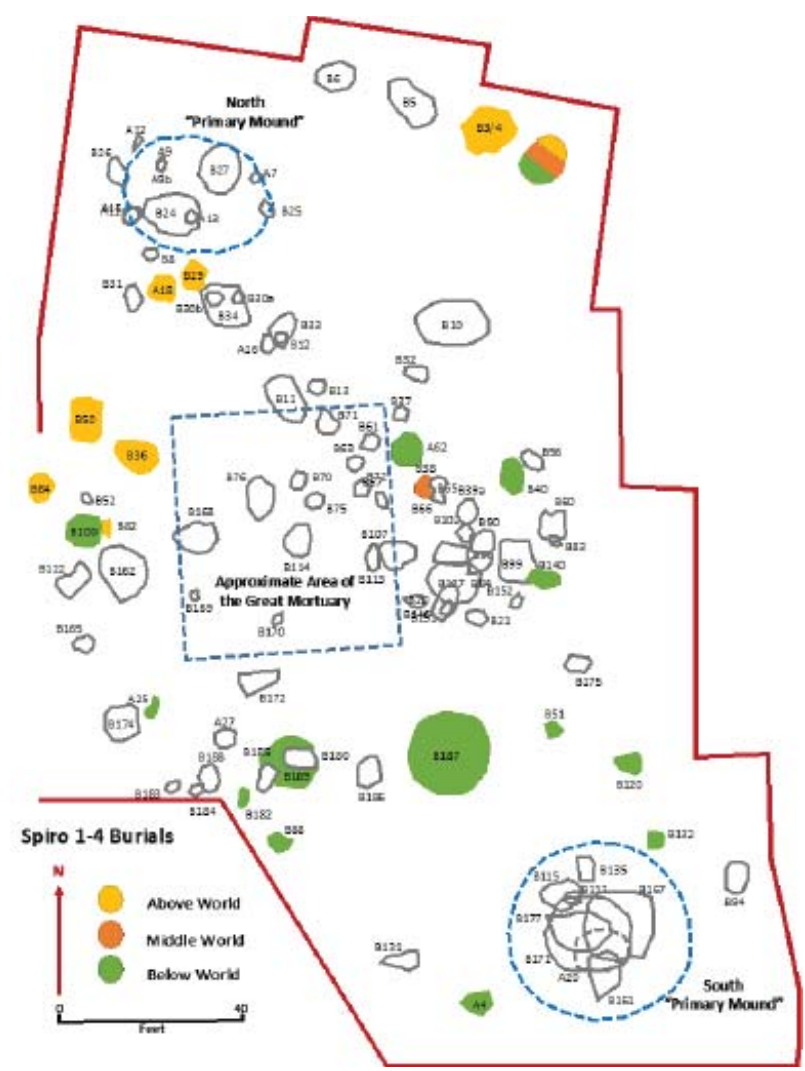

Figure 14. All Craig Mound burials from Spiro I-IV periods.

in which Caddo people built their living environment related to how they structured their cosmological worlds. Like Brown and McKinnon, Sabo also asserted that entire communities and landscapes could be considered as a ritual object.

In this study, I have shown that the Craig

Mound burials not associated with the Great Mortuary or the Spirit Lodge can also be explained as a cosmogram (Figure 14). I also stress that earlier Craig Mound burials may have been used to place highly decorative Caddo vessels to represent the Caddo's cosmological structure, which is something not seen in later Spiro IVB burials (ca. AD. 1400-1450) from the Great Mortuary or the Spirit Lodge. The only pottery interred in the Great Mortuary and the Spirit Lodge now is roughly made plain ceramic vessels that most likely were locally made at Spiro (Hammerstedt et al. 2015). Decorative vessels seemed to have been replaced with other objects, such as gorgets, copper plates, engraved shell cups, and other objects. I would argue that the increases social interaction between Caddo communities with other late prehistoric groups in conjunction with an intensified participation in the Southeastern Ceremonial Complex altered the ways in which Craig Mound participants structured their cosmos.

\section{Conclusions}

So much can be learned from Craig Mound ceramics, and once they are investigated as thoroughly as other Southeastern Ceremonial Complex artifacts that came from the Great Mortuary and the Spirit Lodge, the more fine-grained our interpretations of Spiro will become. Ceramics from Spiro I -IV burials highlight that ceramic iconography can now be used to address a multitude of research interests, such as Caddo rituals and their overall cosmological structure in time and space. Interesting to note here that Spiro Engraved vessels were deposited in Craig Mound from Spiro I through Spiro IV Periods, which suggests that many could be considered heirloom objects by the time of their deposition.

The research value of these ceramics has resulted in important contributions to the archaeological understanding of Caddo imagery, rituals, and cosmology. The study of the composite vessel drawing from the Craig Mound revealed that the known universe of Craig Mound participants was portrayed on one pot, but the reason(s) it was constructed and the meanings behind the representational images are still up for debate. The decorative themes on each section of the vessel, which certainly needs further consideration, may be specific iconographic compositions representing different cosmological realms. The creation of the stacked vessel was most likely not made at Spiro (perhaps along the Red River?), and its journey and placement in the northeast corner of the Craig Mound suggests it was a highly valuable object. This cosmos vessel was placed in the Craig Mound at the same time when we see a significant increase in the deposition of other highly decorative pottery. Thus, after the pot was coiled, engraved, dried, and fired, it was eventually obtained by Craig Mound participants and placed with a burial as an integral part of the Craig Mound's cosmological construction. Using the composite vessel as a way in which to decode other Craig Mound ceramics led to the identification of temporal and spatial patterns 
(Spiro III and III/IV Burials), suggesting Craig Mound participants may have had a specific ritual formula to bury their dead in time and space. This exploration of what the Craig Mound vessels represent helps to illustrates their research potential, to find what was once lost, and to spur novel archaeological interpretations. With future research, I plan to study the directionality of Craig Mound burials as well as include other funerary objects in the burials to assess whether the cosmogram hypothesis still holds true with the additional data. Once this is complete, other contemporaneous ceremonial centers can be examined for similar temporal and spatial iconographic patterns.

\section{References Cited}

Bailey, Garrick A.

1995 The Osage and the Invisible World: From the Works of Francis La Flesche. University of Oklahoma Press, Norman.

Blitz, John H.

1993 Ancient Chiefdoms of the Tombigbee. University of Alabama Press, Tuscaloosa.

Braun, David P.

1991 Why Decorate a Pot? Midwestern Household Pottery, 200 B.C.-A.D. 600. Journal of Anthropological Archaeology 10:360-397.

Brown, James A.

1996 The Spiro Ceremonial Center: The Archaeology of Arkansas Valley Caddoan Culture in Eastern Oklahoma. Memoirs No. 29. Museum of Anthropology, University of Michigan, Ann Arbor.

2012 Spiro Reconsidered: Sacred Economy at the Western Frontier of the Eastern Woodlands. In The Archaeology of the Caddo, edited by Timothy K. Perttula and Chester P. Walker, pp. 117-138. University of Nebraska Press, Lincoln.

2014 Ideological Referents of the Spirit Lodge. Paper presented at the Southeastern Archaeological Conference, Memphis.
Crown, Patricia, Thomas E. Emerson, Jiyan Gu, W. Jeffrey Hurst, Timothy R. Pauketat, and Timothy Ward 2012 Ritual Black Drink Consumption at Cahokia. Proceedings of the National Academy of Science. 109(35):13944-13949.

Dorsey, George A.

1904 Traditions of the Skidi Pawnee. Memoirs of the American Folklore Society, Vol. VIII. HoughtonMifflin and Company, Boston.

Dowd, Elsbeth L.

2011 Amphibian and Reptilian Imagery in Caddo Art. Southeastern Archaeology 30(1):79-95.

Dye, David H.

2011 Mississippian Ceramic Art in the Lower Mississippi Valley. In Visualizing the Sacred: Cosmic Visions, Regionalism, and the Art of the Mississippian World, edited by George E. Lankford and F. Kent Reilly III, pp. 99-117. University of Texas Press, Austin.

2012 Mississippian Religious Traditions. In The Cambridge History of Religions in America, Vol. 1: Pre-Columbian Times to 1790, edited by Stephens J. Stein, pp. 137-155. Cambridge University Press, New York.

Early, Ann M.

2012 Form and Structure in Prehistoric Caddo Pottery Design. In The Archaeology of the Caddo, edited by Timothy K. Perttula and Chester P. Walker, pp. 26-46. University of Nebraska Press, Lincoln.

Fields Ross, C. and Eloise F. Gadus

2012 Archeology of the Nadaco Caddo: The View from the Pine Tree Mound Site (41HS15), Harrison County, Texas. 2 Vols. Report of Investigations No. 164. Prewitt and Associates, Inc., Austin.

Fletcher, Alice C. and Francis La Flesche

1911 The Omaha Tribe. Twenty-Seventh Annual Report of the Bureau of American Ethnology (19051906). Government Printing Office, Washington, D.C. 
Fogelin, Lars

2007 The Archaeology of Religious Ritual. Annual Review of Anthropology 36: 55-71.

2008 Deligitimizing Religion: The Archaeology of Religion As Archaeology. In Belief in the Past: Theoretical Approaches to the Archaeology of Religion, edited by Kelley Hays-Gilpin and David S. Whitley, pp. 129-141. Left Coast Press, Walnut Creek.

Fowles, Severin M.

2013 An Archaeology of Doings: Secularism and the Study of Pueblo Religion. School for Advanced Research Press, Austin.

Gadus, Eloise F.

2013 Twisted Serpents and Fierce Birds: Structural Variation in Caddo Engraved Ceramic Bottles Motifs. Bulletin of the Texas Archeological Society 84:215-247.

Hammerstedt, Scott, Amanda Regnier, and Sheila Salvage.

2015 Color Symbolism in the Arkansas River Valley. Paper presented at the Southeastern Archaeological Conference, Nashville.

Hart, John P. and Timothy K. Perttula

2010 The Washington Square Mound Site and a Southeastern Ceremonial Complex Style Zone among the Caddo of Northeastern Texas. Midcontinental Journal of Archaeology 35(2):199228.

Horton, Elizabeth

2010 The Ties that Bind: Study of Ozark Plateau Textiles. Ph.D. Dissertation, Department of Anthropology, University of Arkansas, Fayetteville.

Howard, James H.

1965 The Ponca Tribe. Bulletin 195. Bureau of American Ethnology, Smithsonian Institution, Washington, D.C.
Joyce, Rosemary A.

2012 What Should and Archaeology of Religion Look Like to a Blind Archaeologist? In Beyond Belief: The Archaeology of Religion and Ritual, edited by Yorke M. Rowan, pp. 180-188. Wiley and Blackwell Publishing, New Jersey.

Kay, Marvin and George Sabo III

2006 Mortuary Ritual and Winter Solstice Imagery of the Harlan-Style Charnel House. Southeastern Archaeology 25(1):29-47.

Knight, Vernon J.

2013 Iconographic Method in New World Prehistory. Cambridge University Press, Cambridge.

Knight, Vernon J., James A. Brown, and George E. Lankford

2001 On the Subject Matter of Southeastern Ceremonial Complex Art. Southeastern Archaeology 20(2):129-141.

Kubler, George

1962 The Shape of Time: Remarks on the History of Things. Yale University Press, New Haven.

Lambert, Shawn P.

2014 Revealing Spiro's Lost Art: The Research Potential of WPA Artifact Illustrations from Craig Mound. In Visions of Other Worlds: Ideological and Ritual Functions of Mississippian Symbols, edited by Kevin Smith. University of Florida Press, Gainesville, in press.

Lankford, George E.

2008 Looking for Lost Lore. University of Alabama Press, Tuscaloosa.

2014 Following the Noded Trail. The Arkansas Archaeologist 53:51-68.

Lankford, George E., Kent F. Reilly, and James F. Garber (editors)

2011 Visualizing the Sacred: Cosmic Visions, Regionalism, and the Art of the Mississippian World. University of Texas Press, Austin. 
McKinnon, Duncan P.

2013 Landscape as a Ritual Object: Exploring Some Thoughts on Organized Space in the Great Bend Region in Southwestern Arkansas. Caddo Archeology Journal 23:67-84.

2015 Zoomorphic Effigy Pendants: An Examination of Style, Medium, and Distribution in the Caddo Area. Southeastern Archaeology 34(2):116-135.

2016 Distribution of Design: The Rayed Circle. Caddo Archeology Journal 26:29-42.

Miller, Jay

1996 Changing Moons: A History of Caddo Religion. Plains Anthropologist 40(157):243-259.

Merriam, Larry G. and Christopher J. Merriam

2004 The Spiro Mound, a Photo Essay: Photographs from the Collection of Dr. Robert E. Bell. Merriam Station Books.

Nash, Louisa

2017a The Cosmos in Clay: An Analysis of Avery Engraved Vessel Motifs. Unpublished Master's Thesis. Cornell University, Ithaca.

2017b The Cosmos in Clay: An Analysis of Avery Engraved Vessel Motifs. Caddo Archeology Journal 28:38-59.

Pauketat, Timothy R.

1989 Monitoring Mississippian Homestead Occupation Span and Economy Using Ceramic Refuse. American Antiquity 54:288-310.

2013 An Archaeology of the Cosmos: Rethinking Agency and Religion in Ancient America. Routledge Press, New York.

Pauketat, Timothy R. and Thomas E. Emerson 1991 The Ideology of Authority and the Power of the Pot. American Anthropologist 93(4):919-941.
Perttula, Timothy K.

2012 The Archaeology of the Caddo in Southwest Arkansas, Northwest Louisiana, eastern Oklahoma, and East Texas. In The Archaeology of the Caddo, edited by Timothy K. Perttula and Chester P. Walker, pp. 1-25. University of Nebraska Press, Lincoln.

2017 Caddo Landscapes in the East Texas Forests. Oxbow Books, Oxford.

Phillips, Erin

2012 Social Contexts of Production and Use of Pottery Engraved in the Hemphill Style at Moundville. Ph.D. Dissertation, Department of Anthropology, University of Alabama, Tuscaloosa.

Phillips, Phillip and James A. Brown

1978 Pre-Columbian Shell Engravings from the Craig Mound at Spiro, Oklahoma. Peabody Museum of Archeology and Ethnology, Harvard University, Cambridge.

Rees, Mark A.

1997 Coercion, Tribute, and Chiefly Authority: The Regional Development of Mississippian Political Culture. Southeastern Archaeology 16(2):113-133.

Reilly, Kent F.

2004 People of the Earth, People of the Sky: Visualizing the Sacred in Native American Art of Mississippian Period. In Hero, Hawk, and Open Hand: American Indian Art of the Ancient Midwest and South, edited by Richard F. Townsend and Robert V. Sharp, 125-137. Art Institute of Chicago and Yale University Press, New Haven.

2007 The Petaloid Motif: A Celestial Symbolic Locative in the Shell Art of Spiro. In Ancient Objects and Sacred Realms: Interpretations of Mississippian Iconography, pp 39-55. Edited by Kent F. Reilly and James F. Garber. University of Texas Press, Austin. 
Reilly, Kent F. and James F. Garber (editors)

2007 Ancient Objects and Sacred Realms:

Interpretations of Mississippian Iconography.

University of Texas Press, Austin.

Rogers, Daniel J.

2009 The Spiro Site. In Archaeology in American: An

Encyclopedia, edited by Francis P. McManamon, pp. 324-329. Greenwood Press, Westport.

2011 Artifacts from the Craig Mound at Spiro, Oklahoma. Smithsonian Contributions to Anthropology 49. Smithsonian Institution Scholarly Press, Washington, D.C.

Sabo, George III

2012 The Teran Map and Caddo Cosmology. In The Archaeology of the Caddo, edited by Timothy K. Perttula and Chester P. Walker, pp. 431-448. University of Nebraska Press, Lincoln.

2014 Paired Figures Confronting a Forked Pole: So What's Up with the Forked Pole? Paper presented at the 70th Southeastern Archaeological Conference, November 12-15, Greenville, SC.
Straten, Roelof van

1994 An Introduction to Iconography. Gordon and Breach Science Publishers, Victoria, Australia.

Steponaitis, Vincas P., Megan C. Kassabaum, and John W. O'Hear

2015 Cahokia's Coles Creek Predecessors. In Medieval Mississippian: The Cahokian World, edited by Timothy R. Pauketat and Susan M. Alt, pp. 12-20. School for Advanced Research Press, Santa Fe.

Swanton, John R.

1929 Myths and Tales of the Southeastern Indian. Bulletin 88. Bureau of American Ethnology, Smithsonian Institution, Washington, D.C.

Waring, A. J. Jr., and Preston Holder

1945 A Prehistoric Ceremonial Complex in the Southeastern United States. American Anthropologist 47(1):1-34. 